\title{
A WORLD WITHOUT BANKRUPTCY
}

\author{
Douglas G. Baird*
}

I

\section{INTRODUCTION}

At the Constitutional Convention in 1787, the only objection to giving Congress the power to pass uniform laws on the subject of bankruptcies was that bankrupts were occasionally put to death in England and that no similar fate should await debtors in this country. ${ }^{1}$ The answer to this objection at the Convention-and one fully borne out over the last two centuries-was that there was little danger of such abuse. ${ }^{2}$ It is useful, however, to recall this barbaric and primitive facet of bankruptcy law in the time of the Framers both to recognize how far our own law has evolved and to instill in us a healthy skepticism when we assume (as all of us who write in the bankruptcy field are wont to do on occasion) that the purposes of bankruptcy law are both obvious and immutable.

The first English bankruptcy statutes gave the creditors of a merchant as a group rights they did not have individually. ${ }^{3}$ These rights arose when a debtor committed certain specified acts. These "acts of bankruptcy," as they were called, focused not on the financial difficulties of the debtor per se, but rather on actions, such as fleeing to "parts unknown," that were thought to thwart the conventional efforts creditors used to obtain repayment. If a merchant committed a specified act of bankruptcy, creditors could petition the Lord Chancellor to appoint a commission that had the power to gather the debtor's assets together and sell them. The commission would then distribute the proceeds "to every of the said creditors a portion, rate and rate alike, according to the quantity of his or their debts." If creditors were not paid off in full, "then the said creditor or creditors, and every of them, shall and may have their remedy for the recovery and levying of the residue of their said debts or duties ... in like manner and form as they should and might have had before the making of this act."4

Bankruptcy law in England began as a debt-collection device for creditors, and the early English statutes were all directed at strengthening the hand of

\footnotetext{
Copyright $\odot 1987$ by Law and Contemporary Problems

- Professor of Law, The University of Chicago.

I thank Frank Easterbrook, Daniel Fischel, Thomas Jackson, and John McCoid for their help.

1. 2 M. Farrand, The Records of Federal Convention of 1787, at 447 (1911); see Nadelmann, On the Origin of the Bankruplcy Clause, 1 AM. J. L. Hist. 215, 221 (1957).

2. 2 M. FarRand, supra note 1 , at 489.

3. 34 \& 35 Henry VIII, ch. 4 (1542). A brief review of the history of bankruptcy law may be found in D. Baird \& T. Jackson, Cases, Problems, and Materials on Bankruptcy 20-30 (1985).

4. 13 Eliz., ch. $7, \S \times(1570)$.
} 
the creditors and increasing their chances of being paid, not at providing relief for debtors. The Statute of 4 Anne, which introduced the concept of discharge to bankruptcy, is a good example. Titled "An act to prevent frauds frequently committed by bankrupts," the statute was an attempt to reduce the problems creditors had in locating their debtor's assets by rewarding those debtors who helped creditors locate and gather their assets and punishing those who did not. ${ }^{5}$ The Statute of 4 Anne provided that those debtors who cooperated fully would be discharged and would take five percent of whatever assets were gathered. Debtors who did not meet with their creditors, who lied to them, or who refused to reveal the whereabouts of all their assets would be hanged. ${ }^{6}$

Congress's exercise of the bankruptcy power was far from inevitable. Indeed, for much of the nineteenth century, there was no federal bankruptcy statute at all. ${ }^{7}$ That we might live in a world without bankruptcy law or any similar collective procedure is not as far-fetched or as ridiculous as it might seem at first glance to those of us who are immersed in its intricacies every day. This article will take problems that have been the focus of much of the recent debate in bankruptcy law and ask how these issues would be approached if no bankruptcy law existed.

The reason for engaging in this thought experiment is not that it is either wise or at all likely that we abandon bankruptcy law. I think neither is the case. Rather, the point of the exercise is to isolate bankruptcy issues from other issues. One of the most troublesome aspects of most modern discussion of bankruptcy law, both academic and judicial, is the reliance upon unarticulated notions of "bankruptcy policy." Imagining the world without bankruptcy law gives us an opportunity to identify precisely what it is that bankruptcy law adds to our legal regime and hence what bankruptcy policy is or should be. This article will show that much of what is usually thought of as "bankruptcy policy" is not bankruptcy policy at all, but rather an issue of general concern that must first be grappled with before the special problems that arise by virtue of a bankruptcy proceeding are confronted. Recognizing

5. 4 Anne, ch. 17 (1705). The preamble to the statute reads: "Whereas many persons have and do daily become bankrupt, not so much by reason of losses and unavoidable misfortunes, as to the intent to defraud and hinder their creditors of their just debts and duties to them due and owing; for the prevention thereof, be it enacted . . . ."

6. The capital punishment provision in 4 Anne, ch. 17 (1705), is contained in the provision of the statute that uncooperative debtors would "suffer as a felon without the benefit of clergy," the eighteenth-century term of art for the death penalty. This is not, of course, to suggest that all debtors who were the least bit uncooperative were executed. Nevertheless, a number of debtors were in fact executed under the Statute of Anne. See, e.g., 1756 Old Bailey Session Papers vol. 2, at 85 (Alexander Thompson, having failed to respond to a notice to appear before a bankruptcy commission, executed despite claim that he had no knowledge of the notice because he had been in the north of Scotland when it was made); 1761 Old Bailey Session Papers vol. 8, at 394 (John Perrot executed for trying to hide some bank notes from his creditors after being adjudicated a bankrupt).

7. The Bankruptcy Act of 1800, 2 Stat. 19, was repealed in 1803. The Bankruptcy Act of 1841 , 5 Stat. 440, was repealed after only eighteen months. Congress passed another bankruptcy statute in 1867, 14 Stat. 517, and repealed it in 1878. The Bankruptcy Act of 1898 survived, with substantial amendments, until 1979. For a history of bankruptcy law in this country, see C. WARREN, BaNKRUPTCY LaW In United States History (1935). 
that a problem involves the rights of tort victims or the hazards of toxic wastes and not bankruptcy policy does not make the problem go away, but it does identify with greater clarity the relevant stakes. The first issue I want to address is the problem of individual debtors who are unable to pay what they owe.

\section{II}

\section{The Problem of Discharge}

We live in a world of limited liability. Everyone's assets are limited. Each of us possesses only a finite amount of real and personal property. Moreover, the most valuable asset for nearly all of us-the present value of what we shall earn during the remainder of our working lives-is finite as well. We all must reckon with the possibility that we might incur obligations that we are incapable of meeting. A fundamental question we would need to address, even if there were no bankruptcy law at all, is whether this fact of limited liability should affect the rules of debt collection. We need to ask, in other words, whether the right of creditors to bring suit, reduce their claims to judgment, and have the sheriff levy on or garnish our assets should be limited by anything other than whether we have assets.

One could argue that such limits should not exist. Limitations on the ability of creditors to obtain repayment ultimately make it more difficult for debtors to obtain credit in the first instance. Moreover, debtors who are concerned about falling too deeply into debt can organize their affairs to minimize the chances of it happening. For example, a debtor may be able to take out insurance to protect himself against tort suits. A debtor may also be able to buy insurance to protect himself if he becomes disabled and is unable to continue work. Finally, one can argue that to the extent that we are worried that the creditors' efforts to obtain repayment will leave the debtor destitute, the problem is no different from one we encounter when someone is left destitute through some other misfortune.

This argument, if followed to its logical extreme, first suggests that there should be no discharge right in bankruptcy or anywhere else; and second, that if such a right does exist, it should be, like virtually all other rights, one that people can waive. English history dramatically illustrates that discharge is not a necessary part of a bankruptcy statute. Indeed, discharge has not always been a feature of this nation's bankruptcy laws, and, as the Supreme Court has noted, discharge "is a legislatively created benefit, not a constitutional one."

Professor Thomas Jackson has shown that there are sound reasons for limiting the right of creditors to reach all of a debtor's assets. ${ }^{9}$ Limiting the right of creditors to reach assets imposes a burden on creditors to monitor their debtor and ensure that he does not become overextended. In such a world, both creditors and debtor want to insure that the debtor has enough

8. United States v. Kras, 409 U.S. 434, 447 (1973).

9. Jackson, The Fresh-Start Policy in Bankruplcy Law, 98 HARv. L. Rev. 1393 (1985). 
assets to pay what he owes. A bank that makes a loan may not be as much an adversary as a partner. More to the point, one may not be able to rely upon individual debtors to determine correctly at the time they borrow the wisdom of limiting the right of creditors to take their property and reach their future income. Debtors might not take account fully of the effect that the loss will have on others, such as spouse, family, and other dependents.

In addition, people may not be able to weigh without bias present consumption (through a larger loan) against greater further hardship (as a result of a less limited check upon creditor remedies). Some people often have poor impulse control. Just as most of us who walk into a casino make sure that we carry only a limited amount of money, most of us might also favor living in a world in which the option of getting more money now in exchange for losing a right to a discharge is not available. ${ }^{10}$ Similarly, individuals may have a tendency to underestimate bad outcomes and overestimate good ones. We tend to overlook the millions of ways in which our plans can go awry, and hence we think it more likely than is the case that we shall be able to repay a loan. ${ }^{11}$

Limits on the ability of creditors to reach assets, however, cannot be so severe that they cripple credit markets and undermine the ability of people to borrow in the first instance. In a market economy, few of us could buy a house or go to law school (or, indeed, college) were credit not available. Some commentators have recently suggested that bankruptcy law should be amended to allow creditors to look at a portion of the debtor's future earnings. ${ }^{12}$ Implicit in this approach is the argument that the "honest but unlucky debtor" that bankruptcy law is designed to help can begin again even if he does not enjoy the use of all his future income.

10. This is known as the problem of impulse control. The classical metaphor for this phenomenon is Ulysses. Just as Ulysses wanted to be tied to a mast and thus rendered unable to succumb to the song of the Sirens, we may want to be protected from the lures of consumer lenders. See J. Elster, Ulysses and the Sirens: Studies in Rationality and Irrationality (1979).

11. The cognitive devices that we use for processing information and that serve us well for handling problems of immediate concern may not serve us well when we are judging the probability of distant and uncertain events. See Tversky \& Kahneman, The Framing of Decisions and the Psychology of Choice, 211 Science 453 (1981). The literature on cognitive dissonance is an extensive one. For a review of it, see Edwards \& von Winterfeldt, Cognitive Illusions and Their Implications for the Law, 59 S. CAL. L. REv. 225 (1986). Experimental evidence suggests that individuals ignore sample size and base rates in assessing the likelihood of future events. In addition, they are too heavily influenced by experiences they remember most vividly and the point at which they start analyzing a problem. For an example of some of the empirical work supporting the concept, see Tversky \& Kahneman, Judgment Under Uncertainty: Heuristics and Biases, 185 SCIENCE 1124 (1974). For an argument that the law should not take cognitive dissonance into account, see Scott, Error and Rationality in Individual Decision-Making: An Essay on the Relationship Between Cognitive Illusions and the Management of Choices, 59 S. CAL. L. Rev. 329 (1986).

12. See, e.g., Credit Research Center, Krannert Graduate School of Management, Purdue UNIVERSITY, 2 Consumer Bankruptcy Study (1982). As part of its amendments to the Bankruptcy Code in 1984, Congress gave the bankruptcy judge the power to dismiss a consumer's chapter 7 petition and hence deny a debtor the freedom to enjoy future income free of his creditors' claims where granting relief would be a substantial abuse of the bankruptcy process. 11 U.S.C. \& 707(b) (Supp. II 1984). A bankruptcy judge may exercise this power when a debtor appears to be able to repay a substantial part of his prebankruptcy debts out of his future income. See, e.g., In re Grant, 51 Bankr. 385 (Bankr. N.D. Ohio 1985). 
Professors Teresa Sullivan, Elizabeth Warren, and Jay Westbrook have argued that the evidence does not support the assertion that those who file for bankruptcy can pay what they owe out of future income. ${ }^{13}$ But regardless of how effective or fair such a change in bankruptcy law would be, such proposals do show that there are many different ways in which someone can be protected from his creditors. Instead of insulating future income, one can insulate present assets or some combination of the two. Each constitutes a part of an individual's "wealth." Moreover, once one realizes that a bankruptcy statute does not necessarily have to free a debtor's future income in order to give him a fresh start, one should also see that the limitations bankruptcy law and state law places on the ability of creditors to reach assets are not fundamentally different. Many states have statutes that limit the amount of a debtor's wages that can be garnished. ${ }^{14}$ All states, in addition, protect certain assets by exemption laws. There are also laws that prohibit using some kinds of property as collateral and others that prohibit the transfer of some kinds of property, such as social security benefits, ${ }^{15}$ altogether.

A bankruptcy proceeding may provide a better forum for dividing among multiple creditors the wages that can be reached, but this is a question of rights as among creditors and not rights between creditors and a common debtor. Hence, before one asks whether debtors should be able to free future income from past debt, one needs to ask the more general question of what ought to be the proper scope of the limitations on the creditors' rights.

Imagine a debtor who has retired and has $\$ 100,000$ invested in a mutual fund. He rents an apartment, which is modestly furnished, and he does not own a car. He becomes liable for a $\$ 200,000$ tort judgment as a result of professional malpractice and has $\$ 20,000$ in other obligations. Imagine another debtor who has not retired and earns $\$ 40,000$ a year. He owns a house with $\$ 30,000$ of equity and also owns the furniture in his house and a car that is worth $\$ 1,000$ more than what he still owes on it. He also becomes liable for a $\$ 200,000$ tort judgment, also as a result of professional malpractice, and has $\$ 20,000$ in other obligations. Under existing law, the limitations on the rights of the creditors of these two debtors are quite different. In most states, there would be few limits on the ability of creditors to reach the first debtor's primary asset, his interest in the mutual fund. State exemption statutes and federal bankruptcy law, however, would allow the second debtor to enjoy at least a portion of the equity in his home and might allow him to keep his car and his furniture as well. Federal bankruptcy law would, moreover, allow the second debtor to shield all of his future income from the claims of his creditors. In combination, state and federal law would

13. See Sullivan, Warren \& Westbrook, Limiting Access to Bankruptcy Discharge: An Analysis of the Creditors' Data, 1983 WIS. L. REv. 1091.

14. E.g., Cal. Civ. Proc. Code $\$ 704.070$ (b)(2) (West Supp. 1976); N.Y. Civ. Prac. Law $\S 5205$ (d)(2) (McKinney 1978). In addition, the Consumer Credit Protection Act, 15 U.S.C. $\$ 1601$ (1982), limits the extent to which any one creditor may garnish wages of an individual.

15. 42 U.S.C. $\S 407$ (1982). 
insulate nearly all of the second debtor's assets from the claims of creditors and almost none of the first's. ${ }^{16}$

To point out that such differences exist, of course, is not to say that they should not exist. But it should sound a note of caution. As we try to unravel the mysteries of the sections of the Bankruptcy Code defining property of the estate ${ }^{17}$ and exemptions, ${ }^{18}$ particularly if we are in the business of advocating legislative reform, we have to understand the purposes behind limiting the ability of creditors to reach assets. It is simply not enough to say that giving the honest but unlucky debtor a fresh start is the policy that underlies existing law. The current mix of bankruptcy law, state law, and nonbankruptcy federal law gives "fresh starts" of varying dimensions to different kinds of debtors.

Before one reaches questions of how the Bankruptcy Code itself ought to be reformed, one needs to understand exactly what kind of fresh start debtors should be given and why creditors' rights to reach some kinds of property are different from their rights to reach other kinds of property. The differences that exist under current law are, of course, capable of some explanation. Freeing a debtor's future earnings provides incentives to bring the assets into being in the first instance, and exempting some kinds of property may make sense if the property is worth more in the debtor's hands than in his creditors'. Moreover, no explanation will cover all cases. One needs to bear in mind that legal rules will never be perfect. We must inevitably draw lines that separate similar cases. What matters is that basic differences can be justified, not that every case, no matter how anomalous, falls neatly into appropriate categories. Nevertheless, both the concept of exempt property and the extent to which a debtor should be able to insulate future income from past debts are in flux, and the lines between present assets and future income and exempt and nonexempt property are not as clear as they might at first seem. For example, there may be little difference between taking $\$ 20,000$ from the debtor's bank account and allowing him to enjoy his $\$ 50,000$ a year income on the one hand, and taking nothing from his bank account and garnishing $\$ 10,000$ of his wages each year for two years on the other hand. Exempt and nonexempt property may be as hard to distinguish. Some exempt property may be property that is hard for a debtor to replace but of relatively little value to creditors, such as clothes or furniture, the proceeds from the sale of which may be small. Not all exempt property, however, has

16. See, e.g., Calif. Civ. Proc. Code $\$ 704.010$ (West Supp. 1986) (equity in motor vehicle up to $\$ 1,200$ ); id. $\$ 704.020$ (household furnishings if "ordinarily and reasonably necessary to, and personally used or procured for use by, the judgment debtor and members of the judgment debtor's family" at his principal residence); id. $\$ 704.070$ (garnishment limited to $25 \%$ of wages); id. $\$ 704.730$ (homestead exemption of $\$ 30,000$ for individuals, $\$ 45,000$ for families). Bankruptcy law has its own list of exempt property in 11 U.S.C. $\$ 522$ (1982 \& Supp. II 1984). States, however, are free to opt out of the scheme if they choose. See id. $\$ 522(\mathrm{~b})(1)$. Creditors of an individual debtor who receives a discharge under section 727 can reach only "property of the estate," and section 541 excludes his future earnings from property of the estate.

17. 11 U.S.C. $\$ 541$ (1982 \& Supp. II 1984).

18. Id. $\& 552$. 
this characteristic. Indeed one of a debtor's most valuable exempt assets may be an equity interest in a house that is readily convertible into cash.

We cannot live in a world in which debtors can free themselves of past obligations costlessly and in which credit is easily available. One of the central tasks facing any law reformer is to articulate the limits on the rights of creditors to reach assets, rather than to grapple with metaphysical notions of what is property of the estate or to debate the virtues of state or federal definitions of exempt property. Aphorisms, such as "giving a debtor a fresh start, but not a head start," do not take one very far.

Ohio v. Kovacs, ${ }^{19}$ which was recently decided by the Supreme Court, illustrates the dangers of failing to confront the underlying issues, even when the problem is one of statutory construction rather than legislative reform. William Kovacs ran a hazardous waste disposal business in the 1970's and failed to comply with laws governing the disposal of toxic wastes in contravention of a specific court order to do so. In 1980, Kovacs filed a bankruptcy petition and asserted that his obligation to clean up the toxic wastes he had dumped could be discharged in bankruptcy. The dispute between Kovacs and the state of Ohio focused on whether Kovacs's obligation to clean up the wastes gave rise to a "claim" under 11 U.S.C. section 101(4). If Kovacs's obligations were not a "claim," then the obligation would survive the bankruptcy proceeding.

As Professor Thomas Jackson and I have shown elsewhere, Kovacs's obligation to the state of Ohio must be a "claim" within the meaning of the Bankruptcy Code. ${ }^{20}$ If Ohio did not have a claim against Kovacs, it would have no right to reach his existing assets, as the Bankruptcy Code provides for distribution of property of the estate only to holders of claims. ${ }^{21}$ This result is absurd in the common case in which the disposer of toxic wastes is a liquidating corporation that will dissolve under state law shortly after the bankruptcy proceeding is over. In these cases, Ohio, if it had won in Kovacs, would receive nothing during the bankruptcy because it had no claim. Moreover, Ohio would receive nothing once the bankruptcy proceeding was over, because the person that owed the obligation (the corporation) would have distributed all of its assets to its creditors.

The definition of "claim" in the Bankruptcy Code applies whether the debtor is an individual, who has a chapter 7 discharge right, or a corporation, which does not. Some equitable obligations are excluded from the definition of "claim," but the reasons for this have nothing to do with whether an individual should enjoy a "fresh start." The drafters of the Bankruptcy Code were trying to distinguish two different kinds of obligations: those obligations of a debtor that result from activities engaged in before the filing of the petition, the consequences of which continue to exist even if the debtor goes out of business or dies the moment that the bankruptcy petition is filed, and

19. - U.S. 一, 105 S. Ct. 705 (1985).

20. Baird \& Jackson, Kovacs and Toxic Wastes in Bankruptcy, 36 Stan. L. Rev. 1199 (1984).

21. 11 U.S.C. \& 726 (1982 \& Supp. II 1984). 
those obligations that arise because of the debtor's continued existence and that would disappear if the debtor itself were to disappear. The former category of obligations comes within the Code's definition of claim, while the latter does not. An order to clean up toxic wastes that already have been deposited is a "claim" because the equitable remedy arises out of a prepetition action by the debtor the consequences of which do not depend on the debtor's continued existence. ${ }^{22}$

Excluding some equitable remedies from the definition of "claim," in other words, ensures continued compliance with the law by those who enter into bankruptcy and who continue to exist after the bankruptcy proceeding is over. An order compelling Kovacs to bring his operations into line with the law or to cease dumping wastes in violation of the law would not have been a prepetition claim because it would have addressed future rather than past conduct, and thus it would have survived bankruptcy. An order compelling a cleanup of wastes already dumped was at issue in Kovacs, however. The Supreme Court held, quite correctly, that this obligation to Ohio was a "claim."23 Kovacs, however, left unresolved the question of whether limitations of the right of a creditor to reach a debtor's assets should be lifted because of the nature of that obligation. The relevant provisions of the Bankruptcy Code can be identified most easily if one first examines this issue outside of the bankruptcy context entirely.

Creditors are not able to reach all of a debtor's assets and probably will not be able to in any world that we might encounter. It is possible, however, to have a set of rules that provides that some creditors will face fewer limitations than others. For example, one might reason that banks, consumer lenders, and other voluntary creditors can adjust interest rates and their general business practices to take account of an inability to reach all of every defaulting debtor's assets. These lenders extend credit to many different debtors. They protect themselves both by reaching a recalcitrant debtor's assets and by raising the interest rates they charge all their borrowers. An involuntary creditor (such as a tort victim) may not be in the same position. Similarly, a former spouse or children to whom a debtor owes support cannot protect themselves through diversification. The balance between the ability of creditors to reach assets and the desirability of allowing a debtor to keep assets may be struck differently, depending on the nature of the obligation in question or the person to whom it is owed.

One can characterize the issue in Kovacs as a conflict between environmental law and bankruptcy, but this characterization may not focus matters as sharply as one that treats the case as a conflict over whether Kovacs's obligation to the state of Ohio should be treated differently from his obligation to other creditors (including tort victims and the government in its other capacities, such as tax collector). The distinguishing feature of Kovacs's obligation to Ohio may have had little to do with environmental law. The

22. See Baird \& Jackson, supra note 20, at 1204.

23. Ohio v. Kovacs, $105 \mathrm{~S}$. Ct. at 709. 
usual rule is that an individual can shield future earnings from ordinary tort liability. ${ }^{24}$ If Kovacs's obligation to clean up hazardous waste were the result of mere negligence on his part (or, indeed, the result of strict liability), one might want to find that his obligation was, in fact, dischargeable. In any event, one should want to distinguish this kind of tort liability from other kinds.

As best one can tell from the record in the case, however, Kovacs dumped toxic wastes illegally in the face of a specific court order directing him not to do so. His conduct may have been similar to that of an intentional tortfeasor, whose obligations to his victims are not dischargeable. ${ }^{25}$ If it is the nature of Kovacs's conduct that allows Ohio to reach his future assets, then environmental policy is not what is at issue. Rather, the issue is the distinction we draw between intentional conduct and conduct that is negligent or wholly innocent.

Alternatively, one might argue that an obligation to clean up toxic wastes is similar to an obligation to pay taxes. Because an individual cannot rid himself of his tax obligations, ${ }^{26}$ he arguably should not be able to rid himself of this governmental obligation either. In this case, too, however, the proper approach is one of reasoning by analogy, rather than balancing between "environmental policy" on the one hand and "bankruptcy policy" on the other.

\section{III}

\section{The Rehabilitation of Corporate Debtors}

In the century that followed the introduction of discharge in bankruptcy, relieving individuals of overwhelming debt came to be thought a good in its own right. ${ }^{27}$ Bankruptcy's discharge, as it developed in the eighteenth century, became less of a carrot to induce cooperation by debtors. Merchants, Blackstone observed, needed to borrow, and they should not be left destitute if, as a result of honest entrepreneurial effort, they could not repay what they owed. ${ }^{28}$ Bankruptcy discharge policy was directed towards merchants. Only

24. Exceptions to discharge are contained in 11 U.S.C. $\$ 523$ (1982 \& Supp. II 1984). The exceptions there that are the closest to ordinary tort liability are debts "for willful and malicious injury by the debtor to another entity or to the property of another entity" and debts that arise from "the result of debtor's operation of a motor vehicle while legally intoxicated." This latter provision was added by the 1984 Bankruptcy Amendments.

25. 11 U.S.C. \& 523(a)(6) (1982).

26. Id. $\$ 523(\mathrm{a})(1)$.

27. For an illuminating discussion of changing attitudes towards merchants and credit, see Weisberg, Commercial Morality, the Merchant Character, and the History of the Voidable Preference, 39 STAN. L. REv. 3 (1986).

28. [A]t present the laws of bankruptcy are considered as laws calculated for the benefit of trade, and founded on the principles of humanity as well as justice and to that end they confer some privileges, not only on the creditors, but also on the bankrupt or debtor himself. On the creditors; by compelling the bankrupt to give up all his effects to their use, without any fraudulent concealment: on the debtor; by exempting him from the rigor of the general law, whereby his person might be confined at the discretion of his creditor, though in reality he has nothing to satisfy the debt: whereas the law of bankrupts, taking into consideration the sudden and unavoidable accidents to which men in trade are liable, has given them the liberty of their persons, and some pecuniary emoluments, upon condition they surrender up their whole estate to be divided among their creditors. 
gradually were the benefits of a bankruptcy discharge extended to everyone. During the same period, however, bankruptcy discharge became less important for merchants. Entrepreneurs ceased to need bankruptcy to protect them in the event that their businesses collapsed. The rise of the limited liability corporation and the business trust allowed entrepreneurs to begin businesses without putting their entire net worth at risk.

Today, managers who file a chapter 7 petition on behalf of their corporation cannot possibly share the same motivations as an individual debtor who wants to be released from past obligations. The managers represent the shareholders of the corporation, who already have limited liability under state law. Any assets that the shareholders have not contributed to the firm are insulated from the claims of the firm's creditors. If the corporation fails, the shareholders lose only what they have invested, but no more. The shareholders are free to take their remaining assets-including, of course, their human capital-and invest them in another enterprise.

The stockholders of a failed corporation enjoy a fresh start quite apart from bankruptcy law. When the owners of a corporation decide to wind it up outside of bankruptcy under state law, specified procedures must be followed. ${ }^{29}$ Under these procedures, the shareholders of the corporation are not liable for its debts. On the other hand, they are not entitled to anything until all of the creditors are paid in full. The equity owners are the residual claimants, standing at the end of the line. Everyone with rights to a firm's assets-banks, tort victims, shareholders, and, indeed, many others-may be thought of as "owners" of the corporation. They all have at least a contingent right to reach the firm's assets and the income they generate. Some have priority over others. Secured creditors-bondholders-have priority over general creditors, who have priority over preferred shareholders, who have priority over common shareholders. Some of these parties are called creditors and some of them equityholders. Their attributes vary, but they all share something in common too-they are species of "owners."

Once one takes account of what happens to the owners when a corporation dissolves, there is no "debtor" left to feel sorry for. There may be a fight between two creditors or between creditors and the shareholders, but these should not be thought of as creditor-debtor fights. There may be a fight between different owners of a firm, but that is something quite different. We might care about the rights of particular owners. We might also care about others, such as employees, who might be affected by the failure of a firm. But the idea that a "fresh start" for the corporation is a good in itself is nonsense. A corporation is a judicial but otherwise fictitious being created by the state at the behest of individuals who want to pool assets in a common enterprise. Because anyone-including those who have founded other corporations, successful or not, in the past-can go out and get a corporate charter for less

2 W. Blackstone, Commentaries on the laws of England * 472.

29. See, e.g., Cal. Corp. Code $\$ \$ 1800$ to 2011 (West $1977 \&$ Supp. 1986). 
than a hundred dollars, ${ }^{30}$ no one should be too troubled if a particular corporate charter is torn up. There is nothing to be sentimental about. Corporations and people are not the same.

In a market economy-indeed, in any economy-firms fail. But the failure of a firm is not necessarily a bad thing. Consider the following example. A restaurant in a small town serves heavy, overpriced food that few want. There is a rapid turnover of employees. Waiters come and go particularly quickly because the absence of business means that there is little in the way of tips. The owner of the restaurant is unhappy because he is losing money and all his friends always complain to him about the food and prices at his restuarant. He was much happier in his old job as a bank loan officer.

This restaurant is a firm that has failed. Firms that fail, however, do not disappear without a trace. A restaurant of some kind may continue at the same site. Perhaps a more skillful restauranteur will come in and buy the old owner out. Alternatively, the old owner can bring in a new partner, borrow additional money, change his menu, or hire a new chef. Alternatively, the building that housed the restaurant may be put to a different use and the equipment sold for use in another restaurant.

In contemplating a world without bankruptcy, a crucial question to be considered is whether the set of legal rules outside of bankruptcy law are wanting, whether they fail to ensure that firms that should survive do survive and that those that should not, such as bad restaurants, do not. The common answer is that the dynamics of private bargaining that would exist in a world without bankruptcy would make everyone worse off. The banks, the trade creditors, and the owner, for example, would not take account of the workers who would lose their jobs if the firm failed. Moreover, those involved in the negotiations might be so consumed with their self-interest that they would not allow the owner to take steps less drastic than the wholesale liquidation of the entire business.

This answer, however, is composed of two dramatically different elements, only one of which supports an argument for a bankruptcy law or some other collective creditor remedy. No one doubts that a bankruptcy proceeding serves, in part at least, as a debt-collection device. Sometimes creditors are better off in bankruptcy than outside it. Without a collective bankruptcy proceeding, each creditor will tend to rush towards the debtor's assets when the best course is patience. For example, all the creditors might agree, if they were able to meet and bind one another, that it was in their best interest to give the restaurant owner a second chance. The restaurant might work with a new chef and a new menu, and the value of a successful restaurant-even discounting for the chance of a second failure-is much greater than the value of a restaurant's equipment sold piecemeal. But only a collective proceeding, such as the one federal bankruptcy law provides, might give these diverse owners the chance to pursue such a goal. Only such a collective proceeding

30. See, e.g., Cal. Gov't Code $\& 12201$ (West Supp. 1986) (\$70). 
might be able to restrain individual creditors from trying to obtain payment in full even if it meant that the restaurant did not survive as a restaurant and all the other creditors were left much worse off.

In short, we may not desire a world without bankruptcy because the selfinterest of creditors leads to a collective action problem, and a legal mechanism is needed to ensure that the self-interest of individuals does not run counter to the interests of the group. ${ }^{31}$ But some justifications for the law of corporate reorganizations go far beyond this. They focus not on what is in the interest of the creditors and others with legal rights to the assets of the firm as a group, but rather on what is in the interest of society at large. These justifications assume that the occasion on which creditors need to invoke bankruptcy law in order to solve a collective-action problem is also the occasion for taking account of not merely the creditors' interests, but also those of others, such as employees who will lose their jobs if a hardware store replaced the restaurant.

This view of why bankruptcy law is needed suffers from an obvious difficulty: It may be impossible to discover what course best advances society's interests at large. Even if one wants to save jobs, it does not follow that allowing a bad restaurant to fold reduces the number of jobs in the economy. The hardware store that replaced the restaurant might, in fact, hire more people. The person who bought the restaurant equipment might open another restaurant in a different city, become very successful, and need to hire more workers than the owner of the bad restaurant.

In addition, embracing a "rehabilitation" goal as a matter of bankruptcy policy does little to resolve many bankruptcy disputes. For example, one of the most common disputes in bankruptcy law is over the question of priorities. When there are not enough assets to go around, some creditors are not going to be paid in full. There is nothing bankruptcy law can do to change this, regardless of what goals it embraces. A dispute over priorities, moreover, has nothing to do with the question of whether a firm should stay in business to save jobs. A rehabilitation goal of bankruptcy should not, to pick an example, lead one to favor denying secured creditors the time value of their claims during the pendency of a bankruptcy proceeding. If secured creditors are paid more, general creditors are paid less and vice-versa. The priority question, however, should have nothing to do with the question of whether the restaurant remains in business and jobs are saved. How the assets are used may, of course, determine how valuable they are, but how assets are used is independent of who gets them. ${ }^{32}$ Even if one embraces a general rehabilitation goal for bankruptcy law, the law will often have little to

31. For a discussion of bankruptcy law as a common-pool problem, see D. BaIRD \& T. JACKson, supra note 3 , at 31-35.

32. This problem is discussed at length in Baird \& Jackson, Corporate Reorganizations and the Treatment of Diverse Ownership Interests: A Comment on Adequate Protection of Secured Creditors in Bankruptcy, 51 U. Chi. L. Rev. 97 (1984). 
say with respect to the many bankruptcy disputes that arise over rights to particular assets rather than the use to which the assets are put.

These observations about having a rehabilitation goal in bankruptcy, however, pale beside the one that is fundamental. The central failing of modern bankruptcy scholarship, however, is that it assumes away the threshold question, which is whether mitigating the effects of firms that fail should be a peculiar concern of bankruptcy law. Firms often fail without a bankruptcy petition ever being filed. ${ }^{33}$ Indeed, a firm can fail without defaulting to its creditors. A plant can close its doors and leave its workers without jobs even when it can pay all its creditors. Bankruptcy arises when a firm cannot meet its obligations and the creditors cannot resolve their competing claims without a collective proceeding. Given the narrow range of cases involving failed firms that are bankruptcy cases, it seems strange to worry about problems like those of former workers in bankruptcy and not elsewhere.

If the law forces those with rights to a firm's assets to consider the interests of workers who might lose their jobs, it should not matter whether the owners of the firm choose to take advantage of the bankruptcy laws. Requiring those with rights against a firm's assets to take account of the interests of the workers is tantamount to giving the workers rights to the firm's assets. It seems odd, however, to create such rights, but have them recognized only in the minority of cases, such as those cases in which the failing firm is in a bankruptcy proceeding. The reasons for using bankruptcy or some other collective creditor remedy have little to do with whether workers who may lose their jobs when the firm fails should have any rights in the matter. There is no reason to live in a world that divides those who worked for failing firms into two categories and protects those in one but not the other. Even if there were some types of workers we wanted to protect and others we did not, it should not turn on whether the creditors or managers of the workers' firm invoked one kind of legal procedure rather than another to rearrange the financial structure of the firm.

Indeed, creating rights in a piecemeal fashion by recognizing some rights in bankruptcy, but not elsewhere, brings significant costs of its own. To the extent that the existence or the extent of substantive rights turns on whether one is inside of bankruptcy, some creditors or managers will use or threaten to use a bankruptcy proceeding even when there is no reason to collectivize the debt-collection process. One cannot think that a firm should be able to repudiate a collective bargaining agreement in bankruptcy, but not elsewhere, and then be surprised if a firm chooses to use bankruptcy to repudiate a collective bargaining agreement and for no other reason. ${ }^{34}$ Firms that simply want to rid themselves of collective bargaining agreements might be denied the use of the bankruptcy process on the ground that such firms act in "bad faith." It makes more sense, however, to decide what obligations a firm in

33. See Baird, The Uneasy Case for Corporate Reorganizations, 15 J. LEGAL STud. 127 (1986).

34. See, e.g., In re Tinti Construction Co., 29 Bankr. 971 (Bankr. E.D. Wis. 1983). 
financial trouble should have with respect to its collective bargaining agreements and to hold these obligations constant inside and outside of bankruptcy.

The existence of our bankruptcy law offers policymakers an opportunity to advance change or reform without squarely debating what they are doing. In a world without bankruptcy, the question of who should have rights to a firm's assets would have to be faced directly. There seems little doubt that Congress could, if it wanted to (and if it acted prospectively), give workers a lien on the assets of a firm or allow firms in financial trouble to repudiate collective bargaining agreements. A law could provide that when any firm liquidated or when its assets were put to a substantially different use, the workers who would lose their jobs as a result would have a right to some fraction of their annual salary, adjusted by the length of their service. Congress could create a regulatory agency and require any firm that wanted to liquidate or change the existing deployment of its assets to go before the agency and make a showing of hardship before implementing its plans. There are any number of other possible laws that might have a similar effect. Such laws may be undesirable for a number of reasons. Other laws might advance the same interests at far less cost. But all of these reforms are possible outside the context of a bankruptcy proceeding. Indeed, they would be possible even if there were no bankruptcy law at all as it is traditionally understood. The justification for preserving the jobs of workers or allowing management to escape from collective bargaining agreements should not be that it vindicates bankruptcy policy, but rather that it is sound policy as a general matter.

We live in a world in which we face many tough issues of social policy and in which we for too long have made altogether casual assumptions about ownership of assets and the priority of those with rights to them. But these issues have nothing to do with bankruptcy law, and we should treat them in our world as we would treat them in a world without bankruptcy.

\section{IV}

\section{THE WORLD WITH BANKRUPTCY}

We have grown too accustomed to living in a world with bankruptcy. We associate the problems of firms in bankruptcy with features of bankruptcy law itself. After observing that firms in bankruptcy usually do not meet their obligations, we confuse cause and effect and conclude that bankruptcy allows firms to escape obligations. A firm that is insolvent will not meet all its obligations quite apart from whether it is in a bankruptcy proceeding or not. The law can do nothing to prevent this. It cannot make assets where none exist. The crucial question is not whether firms in bankruptcy will meet all their obligations. Like other insolvent firms, they will not. The crucial question rather is whether firms in bankruptcy can free themselves of obligations they would have to meet outside of bankruptcy even when they are insolvent. 
A common but largely unexplored assumption is that bankruptcy policy requires changes in the substantive rights creditors and others have against firms that enter bankruptcy proceedings. The Supreme Court, however, has resisted the notion that bankruptcy law creates substantive rights. As it observed in Butner $v$. United States, a party should not receive "a windfall merely by reason of the happenstance of bankruptcy." 35 Two recent cases decided by the Supreme Court provide good illustrations of how bankruptcy law should respond to and incorporate rights that exist outside of bankruptcy.

\section{A. The Problem of Abandonment}

Quanta Resources processed waste oil. ${ }^{36}$ In direct violation of its operating permits, Quanta had dumped hundreds of thousands of gallons of oil contaminated with PCB, a deadly carcinogen, at its plants in New Jersey and New York. Before the state environmental protection agencies could order Quanta to clean up its dump sites, Quanta filed for bankruptcy and moved to liquidate its assets. The trustee, as part of the liquidation, sought to abandon the toxic waste sites. The bankruptcy court approved the abandonment, and the district court affirmed. In its opinion the Supreme Court noted that the trustee had "abandoned" the property in question and that as a result, the state was forced to use its own resources to decontaminate the waste dumps at a cost of about $\$ 2.5$ million. ${ }^{37}$

Perhaps the principal question in the litigation was the nature of the claim that the state had against Quanta. The state had spent $\$ 2.5$ million because of prebankruptcy dumping by Quanta. Under applicable nonbankruptcy law, Quanta was obliged to repay the state for its clean-up efforts. Nothing in bankruptcy law should relieve Quanta of this obligation. A decision to keep property or abandon it should have no affect on obligations that have arisen as a result of past ownership of the property. Abandonment should affect only those obligations that would arise in the future as a result of continued ownership. Much of the discussion of the abandonment issue has been based upon the erroneous assumption that if the trustee could abandon a toxic waste site, he could relieve the estate of any obligations associated with the site that had already arisen. The abandonment of an asset is completely different from the "abandonment" of a liability that may have resulted from ownership of that asset. An accident victim does not lose his right to assets of the debtor when the trustee disposes of the car that ran him over. A state that seeks to recover the costs of cleanup stands in an analogous position.

Although it has nothing to do with whether the trustee can abandon a toxic waste dump, a difficult question does arise with respect to the state's claim against Quanta: the priority of the state's claim relative to the claims of

35. Butner v. United States, 440 U.S. 48, 55 (1979), quoting Lewis v. Manufacturers National Bank, 364 U.S. 603, 609 (1961).

36. These are the facts of Midlantic Nat'l Bank v. N.J. Dep't of Envtl. Protection, 106 S. Ct. 755 (1986).

37. Id. at 758. 
others to whom Quanta also owes obligations. The state's $\$ 2.5$ million claim may be a general claim that is treated the same as the claim of a tort victim or a trade creditor. Another possibility is that the state's claim may be superior to those of others. For example, if the land has value after the cleanup, the state may be entitled to the proceeds from the sale of the land before any of the other creditors. The state may be a general creditor of the debtor-and be forced to share pro rata with others-only to the extent the proceeds from the sale fall short of $\$ 2.5$ million. Alternatively, the state may be entitled to enjoy the proceeds from the sale of all of the debtor's assets to recover its $\$ 2.5$ million before any of the general creditors-or, indeed, even any of the secured creditors.

The answer to this priority question does not lie in the Bankruptcy Code. That the debtor was a wrongdoer may not be relevant. The debtor is not in the picture. The right of the state must be compared to the rights of others whom the debtor may have wronged even more grievously. Nevertheless, however we resolve the question of rights among creditors, one must recognize that the answer to this question should not depend upon whether the debtor happens to be in bankruptcy. The law in this area is not especially well developed, and one would expect that any court facing this question would rely heavily on notions of equitable liens and the like. As a matter of existing law, the place to start in several jurisdictions is with lien statutes that directly address the question of the priority of environmental claims relative to others. ${ }^{38}$ But whether nonbankruptcy law is well developed is quite beside the point. The problem is not a bankruptcy one in the sense that it would exist even if no bankruptcy law existed.

Congress could pass a statute that gave a state priority to all the debtor's assets in bankruptcy but let state law control priorities elsewhere. Such a statute, however, would make little sense. If Congress passes a statute on the priority question, it should apply outside of bankruptcy as well. Otherwise, creditors of a firm such as Quanta would in the future try to keep it out of bankruptcy, while the state would try to put it in. No one would have the incentive to ask the right question-which is whether a bankruptcy proceeding was the best place to sort out the affairs of a firm that was unable to meet all of its obligations. Both the creditors and the state have the right incentive only if the substantive obligations of the firm are the same regardless of the forum in which it is litigated.

The priority question, however, was not before the Court in Midlantic National Bank. ${ }^{39}$ The only issue was whether a trustee could abandon the waste sites in contravention of local laws. The issue may have been moot. In its recounting of the facts, the Court noted several times that the dump sites

38. See, e.g., New Jersey Spill Compensation and Control Act, N.J. Stat. ANN. § 58:10-23.11.f (West 1982 \& Supp. 1986).

39. The Court noted explicitly that the priority of the state's claim relative to the other creditors was not before it. $106 \mathrm{~S}$. Ct. at 758 n.2. 
had already been abandoned.40 What is the effect of holding that the trustee cannot abandon the property, given that he has already done so? The dumps did not seem to pose a continuing hazard because the state had already cleaned them up. What difference would it have made if the Court had ruled that the trustee could abandon the property? In what way would claims against the assets of the estate change? If it would make no difference, then there might not have been a case or controversy.

The firm is liable for the damage caused by the wastes already dumped. Once the liability exists, the trustee's continued ownership of the property would not seem relevant. A right to abandon benefits the estate only if the right frees the estate from obligations that have not yet arisen but rather might arise if the debtor remains the owner of the property. Assume, for example, that Debtor owns a quarry that is currently filled with water and is an attractive nuisance. Debtor is liable in tort to anyone who swims in the quarry and drowns. Debtor might try to sell the property. If it could find a buyer, Debtor might not be liable to anyone who drowned after the sale was consummated. But, of course, a sale of the property now would do nothing to relieve Debtor of its obligations to anyone who had drowned while it owned the property.

Assume, however, that Debtor cannot find a buyer. The benefits of owning the property do not exceed the costs of bearing the tort liability. Debtor might then try to rid itself of the property by purporting to abandon the property. An effort to rid itself of ownership may not be effective. Debtor may not be able to escape the obligations of ownership unless it can find someone else to assume them. Even if Debtor dissolves, the potential liabilty to future tort victims might have to be taken into account when the assets are divided up. ${ }^{41}$ Indeed, even after the corporate dissolution, tort victims could sue the corporation and recover assets that had been distributed to the shareholders. ${ }^{42}$

If these are the constraints Debtor faces outside of bankruptcy, no bankruptcy policy requires changing them. A debtor in bankruptcy should have the same obligations to future drowning victims. A debtor in bankruptcy should have the same legal obligations as everyone else, and one should also turn to nonbankruptcy law to determine the priority of these obligations relative to other prebankruptcy obligations of the firm. If Debtor could not free itself of these obligations through a unilateral act outside of bankruptcy, it should not be able to do so in bankruptcy either.

The Court in Midlantic National Bank faced exactly this kind of problem. The Court should have focused directly on the continuing obligations the trustee would face as a result of ongoing ownership of these toxic waste sites. The Court should have distinguished between obligations that arose because of past ownership and those that would arise in the future because no one was

40. See, e.g., id. at 758 .

41. See, e.g., Cal. Corp. Code $\$ 1905(2)$ (West Supp. 1986).

42. See, e.g., Cal. Corp. Code $\$ 2009$ (West 1977). 
willing to buy the sites and applicable state law did not allow the debtor to walk away from them. Because the dumps had already been cleaned up, there may have been few such latter obligations or even none at all. If there were such obligations, however, they should have continued in bankruptcy. In Midlantic National Bank, the Court declared that a debtor in bankruptcy was bound by the nonbankruptcy limitations on abandoning property because it recognized the state's need to enact regulations "reasonably designed to protect the public health or safety from identifiable hazards." 43 The outcome is surely correct. Nothing explicitly qualifies the trustee's power to abandon under section 554 of the Bankruptcy Code, but implict qualifications must exist. It offends common sense to think, for example, that a trustee in bankruptcy has an unqualified right to litter.

After a notice and a hearing, the trustee has the power to use the property of the estate, to sell it, to lease it, and to abandon it. ${ }^{44} \mathrm{He}$ has these powers so that he can give the general creditors, whom he represents, the largest return possible. The power to sell exists because sometimes the sale of an asset is in the interest of all the general creditors. The abandonment power is no different. The abandonment power exists because some kinds of property are not worth keeping. The trustee should allow a secured creditor to take property that is costly to maintain and that will never bring any returns to the general creditors. The trustee should abandon a lawsuit that is expensive to litigate and that will not bring an award great enough to justify its present cost. Or, more simply, the trustee should abandon a machine that is broken that will cost more to fix than it is worth.

Nonbankruptcy law limits the trustee's power to dispose of property of the estate even though these powers, like the power to abandon, are unqualified in the Bankruptcy Code itself. The trustee can use the debtor's chemistry laboratory, but he cannot use it to make LSD. The trustee can sell the debtor's property, but the sale must be conducted according to nonbankruptcy rules. If these rules forbid the sale of the property in question, the sale cannot take place regardless of how beneficial it might be. If a firm outside of bankruptcy cannot sell its FAA landing slot at a particular airport, a firm inside of bankruptcy cannot sell it either. The virtues of the restrictions on transfer should not be suspect simply because a bankruptcy proceeding has begun. The same principle applies to the power to abandon property. If a firm outside of bankruptcy cannot rid itself of obligations that arise out of continuing ownership of a waste dump, a firm inside should not be able to rid itself of these continuing obligations either. The reison is not, as the Court suggested, that these regulations protect the public safety, but rather that debtors in bankruptcy must play by the same rules as everyone else. Bankruptcy law should not require special scrutiny of these regulations when those affected have filed a bankruptcy petition. Indeed, the ultimate

43. Midlantic Nat'l Bank, 106 S. Ct. at 762.

44. 11 U.S.C. $\$ \S 363(b)(1)$ (trustee's power to use, sell, or lease property) (1982 \& Supp. II 1984); id. $\$ 554$ (abandonment). 
effect of such scrutiny may be to limit the effect of regulations in bankruptcy and thus encourage firms to enter bankruptcy to avoid them.

Midlantic National Bank is a source of potential mischief. The popular press reported that the Court held that firms cannot use bankruptcy to escape obligations to clean up the toxic wastes they have dumped. The Court, in fact, held nothing of the sort. What obligation a debtor owes to the state as a result of prepetition dumping of toxic wastes was not an issue in the case. The only question before the Court was whether bankruptcy law could relieve a debtor of liability that would arise out of future ownership of the property when nonbankruptcy law offered the debtor no means of escaping such liability. This question has a simple answer: A debtor in bankruptcy has to follow the law just like everyone else. Instead of reaching this conclusion directly, the Court embarked first upon a balancing test that looked at the merits of the nonbankruptcy rule. ${ }^{45}$

There is the danger that notwithstanding the Court's explicit disclaimers, lower courts will read Midlantic National Bank as deciding the priority question, or at least interpret it as saying that the priority question turns on a bankruptcy-specific determination of the importance of obligations to clean up the environment relative to other kinds of claims. The proper course is to resolve the priority question by looking at nonbankruptcy law. To the extent lower courts are misled in this way, fewer toxic waste firms will have their affairs sorted out in bankruptcy. More may go out of business without any kind of administrative proceeding at all. Neither environmental law policy nor bankruptcy policy will be vindicated.

There is a further and more subtle danger. Few state regulations governing toxic wastes will fail the Court's "reasonableness" standard. To say that only reasonable regulations governing abandonment of property apply in bankruptcy may be no different from saying that all regulations apply. The opinion, however, reinforces the idea that in bankruptcy, one must balance unidentifiable notions of "bankruptcy policy" against the virtues of other kinds of statutes. This way of looking at the world produces special rules in bankruptcy and encourages firms that would benefit by these special rules to take advantage of the bankruptcy process. Create special rules, and someone will take advantage of them. If labor law or tort law is different in bankruptcy than elsewhere, one cannot be surprised if some seek bankruptcy for that reason and no other. The ultimate effect of Midlantic National Bank and its endorsement of tempering the effect of nonbankruptcy rules in bankruptcy may be to encourage precisely the abuse of the bankruptcy process that the popular press thought the Supreme Court was striking down.

\section{B. Bankruptcy Procedure}

It is one thing to point out that substantive issues should be the same whether they arise in or outside of bankruptcy. But one cannot pretend that

45. $106 \mathrm{~S}$. Ct. at 762. 
the procedures in bankruptcy are the same as they are elsewhere. The whole point of a bankruptcy proceeding is to change procedures so that creditors and others with rights to the firm's assets can act collectively. This naturally raises the question of what principles should guide procedures in bankruptcy, a question made particularly important because the drafters of the Bankruptcy Code left the issue of procedure to later rulemaking and case-by-case adjudication. The Supreme Court faced this issue in Commodity Futures Trading Commission $v$. Weintraub. ${ }^{46}$ In that case, a firm had filed a bankruptcy petition and the trustee wanted information in the possession of the firm's lawyer. The lawyer refused to disclose the information on the grounds of the attorney-client privilege of the corporation. The trustee asserted that he, not the management of the firm, had the right to waive the privilege of the corporation. The trustee did not contend that he could waive any personal privileges held by the managers as individuals. ${ }^{47}$

As long as the corporation exists, someone ought to have the power to assert or waive privileges on its behalf. The question before the Court was one of determining how to identify this person. The Court resisted the temptation to balance the purposes of the attorney-client privilege against vaguely articulated notions of bankruptcy policy. Instead, it compared the substantive changes brought about as a result of the bankruptcy proceeding and the appointment of the trustee with changes that might come about under nonbankruptcy law. The Court observed that because the trustee operated the business and had powers that were similar to the managers of a firm under nonbankruptcy law, the appropriate analogy under nonbankruptcy law was the replacement of old management by new management. ${ }^{48}$

The organizing principle of the law of corporations is that the day-to-day control of the assets should be in the hands of the residual claimants. Shareholders run the affairs of a solvent corporation. They gain a dollar if the corporation gains a dollar; they lose a dollar if the corporation loses a dollar. Because they stand at the margin, they have control over management and the managers owe a duty to them. Treating the trustee as new management may seem to be a shift away from the nonbankruptcy rule because the trustee looks out for the interests of the general creditors rather than the shareholders. But when a firm is insolvent, the residual claimants are the general creditors, not the shareholders. By contrast, the shareholders are unaffected by the changing fortunes of the firm. Except in the most extraordinary circumstances, they will get nothing, regardless of whether the fortunes of the firm rise or fall.

If a firm is insolvent, the shareholders should no longer be in the picture. If the general creditors are not going to be paid in full, the shareholders should not get anything. Those who control any rights that may increase or

46. 105 S. Ct. 1986 (1985). The reasoning in Weintraub was foreshadowed in Comment, Waiver of the Attormey-Client Privilege by the Trustee in Bankruptcy, 51 U. CHI. L. Rev. 1230 (1984).

47. Weintraub, $105 \mathrm{~S}$. Ct. at 1990.

48. Id. at 1993-95. 
decrease the value of the firm's assets should therefore be the general creditors. General creditors, as represented by the trustee, cannot be trusted to look out for the interests of the shareholders, but when the firm is insolvent and there is a day of reckoning, the shareholders' interests should not be looked out for.

As a first approximation, the trustee will waive the attorney-client privilege if it will improve the fortunes of the firm. Hence, the trustee's incentive is not at odds with the interests "of the corporation" if by "interests of the corporation" we mean the interests of those whose rights matter. The old managers will not want the trustee to be able to waive the corporation's attorney-client privilege because the trustee will not care whether the waiver will benefit either the old managers or the shareholders they represented. There is no reason to think, however, that the trustee will waive the privilege when it is contrary to the interests of those who will share in the firm's assets. The unhappiness of the old managers is no different from their unhappiness when there is a hostile takeover. Ownership of assets changes when a bankruptcy petition is filed just as when there is a hostile takeover. In the case of a takeover, it is a purchase of stock in the marketplace; in the case of a bankruptcy proceeding, the filing of the petition effectively changes the ownership. Allowing the trustee to waive the attorney-client privilege puts the right exactly where it belongs: in the hands of the residual claimant, someone who, when he looks out for those he represents, will also look out for the interest of everyone else who matters. Doing this preserves the nonbankruptcy rule. That it makes some people unhappy should not matter here any more than it matters when ownership interests change outside of bankruptcy.

The Court's recognition in Weintraub that a trustee in bankruptcy is the analogue of new management ensured that the bankruptcy proceeding disturbed the rights and obligations of all the players as little as possible. Weintraub is a near perfect illustration of the theme that has sounded throughout this article. It is possible-and, indeed, desirable-to imagine the world without bankruptcy law. Bankruptcy law works against a backdrop of other rights. It can be best understood and disputes in bankruptcy can best be understood when this principle is kept in mind. 
.. 